\title{
Baseline Sensitivity of Didymella bryoniae to Cyprodinil and Fludioxonil and Field Efficacy of these Fungicides Against Isolates Resistant to Pyraclostrobin and Boscalid
}

\author{
Anthony P. Keinath, Coastal Research and Education Center, Clemson University, Charleston, SC 29414-5329
}

\begin{abstract}
Keinath, A. P. 2015. Baseline sensitivity of Didymella bryoniae to cyprodinil and fludioxonil and field efficacy of these fungicides against isolates resistant to pyraclostrobin and boscalid. Plant Dis. 99:815-822.

To prevent yield reductions from gummy stem blight, fungicides often must be applied to watermelon (Citrullus lanatus) and muskmelon (Cucumis melo). Didymella bryoniae, the ascomycete fungus that causes gummy stem blight, is resistant to thiophanate-methyl, quinone-outside inhibitors (QoI), boscalid, and penthiopyrad. In place of these fungicides, premixtures of cyprodinil and fludioxonil (Switch $62.5 \mathrm{WG}$ ) or cyprodinil and difenoconazole (Inspire Super 2.82SC) are used. The objectives of this study were to examine baseline isolates of $D$. bryoniae for sensitivity to cyprodinil and fludioxonil and to determine the efficacy of cyprodinil-fludioxonil and cyprodinil-difenoconazole against isolates resistant to QoI fungicides and boscalid. Colony diameters of 146 isolates of D. bryoniae collected in South Carolina and other U.S. states prior to 2008 were measured on glucose minimal medium amended with cyprodinil or fludioxonil. Mean effective concentration values that reduced relative colony diameter by $50 \%$ were 0.052 and $0.099 \mathrm{mg} /$ liter cyprodinil and fludioxonil, respectively. In autumn 2008, 2009, and 2011, field-grown

watermelon inoculated with isolates resistant to QoI fungicides and boscalid was treated with boscalid-pyraclostrobin alternated with chlorothalonil, cyprodinil-fludioxonil alternated with chlorothalonil, cyprodinil-difenoconazole alternated with chlorothalonil, tebuconazole alternated with chlorothalonil, chlorothalonil, or water. In 2008 and 2011, both cyprodinil treatments reduced disease severity compared with the water control treatment and chlorothalonil alone. In 2008 and 2009, cyprodinil-fludioxonil reduced severity compared with boscalid-pyraclostrobin and, in 2008, cyprodinil-difenoconazole and tebuconazole also did. Use of cyprodinil-fludioxonil should control gummy stem blight effectively and may delay development of resistance to cyprodinil and fludioxonil in D. bryoniae. However, because Botrytis cinerea became resistant to both cyprodinil and fludioxonil after multiple applications of cyprodinil-fludioxonil per season, prudent fungicide rotations should be followed when using cyprodinil-containing fungicides against D. bryoniae.
\end{abstract}

Didymella bryoniae (Auers.) Rehm (= Stagonosporopsis cucurbitacearum (Fr.) Aveskamp, Gruyter \& Verkley) is the ascomycete fungus that causes gummy stem blight on vegetable crops and other plants in the family Cucurbitaceae. Gummy stem blight is particularly severe on watermelon (Citrullus lanatus (Thunb.) Matsum. \& Nakai) and muskmelon (Cucumis melo L.) and often must be managed with fungicides to prevent yield reductions (Keinath 2000, 2014; Seebold 2005). D. bryoniae is resistant to fungicides in Fungicide Resistance Action Committee (FRAC) groups 1 (benzimidazoles and thiophanates), 7 (pyridine-carboxamides and pyrazole-4-carboxamides), and 11 (methoxy-acrylates, methoxy-carbamates, and oximino acetates (Keinath 2009, 2012; Keinath and Zitter 1998; Stevenson et al. 2004; Thomas et al. 2012b). In place of fungicides with these active ingredients, triazoles (FRAC group 3), anilinopyrimidines (FRAC group 9), and phenylpyrroles (FRAC group 12) have become the most important active ingredients used to manage gummy stem blight (Everts and Armentrout 2004; Everts and Zhou 2006; Keinath and Hansen 2013; Langston and Sanders 2010; Sanders and Langston 2013; Seebold 2005; Thomas et al. 2012a; Thornton et al. 2005). A premixture of $37.5 \%$ cyprodinil (FRAC group 9) plus $25.0 \%$ fludioxonil (FRAC group 12) (Switch 62.5WG; Syngenta Crop Protection, Greensboro,

Corresponding author: A. P. Keinath, E-mail: tknth@clemson.edu

This material is based upon work supported, in part, by National Institute of Food and Agriculture/United States Department of Agriculture (USDA) under project number SC-1700446; USDA Specialty Crop Block Grant Program, South Carolina Department of Agriculture Agreement Prime Grant number 12-25-B-1486; and the National Watermelon Association. Technical Contribution Number 6300 of the Clemson University Experiment Station.

Accepted for publication 27 January 2015.

http://dx.doi.org/10.1094/PDIS-09-14-0993-RE

(C) 2015 The American Phytopathological Society
NC) and another fungicide that contains $24.1 \%$ cyprodinil and $8.4 \%$ difenoconazole (FRAC group 3) (Inspire Super 2.82SC; Syngenta Crop Protection) currently are among the main products used to manage gummy stem blight on watermelon and other cucurbits.

In addition to controlling gummy stem blight, cyprodinil plus fludioxonil has been used widely to manage gray mold caused by Botrytis cinerea on grape, strawberry, and blackberry in the field and on tomato, cucumber, and eggplant in greenhouses (Amiri et al. 2013; Baroffio et al. 2003; Fernández-Ortuño et al. 2013; Hilber and Hilber-Bodmer 1998; Li et al. 2014; Myresiotis et al. 2007). Isolates of $B$. cinerea from all six hosts mentioned are resistant to cyprodinil. Frequencies of resistant isolates ranged from 47 to $57 \%$ in four studies (Amiri et al. 2013; Baroffio et al. 2003; Fernández-Ortuño et al. 2013; Myresiotis et al. 2007). The approximately equal proportion of sensitive and resistant isolates follows from the single-gene mode of resistance (Hilber and Hilber-Bodmer 1998).

Fludioxonil applied alone has been used to manage blue mold caused by Penicillium expansum on apple; green mold and blue mold caused by $P$. digitatum and $P$. italicum, respectively, on citrus fruit; and Fusarium dry rot on potato tubers (Gachango et al. 2012; Kanetis et al. 2008; Li and Xiao 2008). Isolates of B. cinerea, P. digitatum, and Fusarium spp. that are resistant to fludioxonil also have been found but the frequency of resistance in most cases was very to relatively low: $0.04,0.7$, and $18 \%$ of $B$. cinerea on grape, blackberry, and strawberry, respectively; 9 and $20 \%$ of isolates of Fusarium sambucinum and $F$. oxysporum, respectively; and 1 in $1.5 \times 10^{5}$ conidia of $P$. digitatum (Amiri et al. 2013; Baroffio et al. 2003; Gachango et al. 2012; Kanetis et al. 2010; Li et al. 2014). However, in a recent survey of $B$. cinerea isolates collected from fungicide-treated strawberry in Germany, 73 to $82 \%$ of isolates were resistant to fludioxonil (Leroch et al. 2013). Resistant isolates possessed a multidrugresistant phenotype characterized by mutations in several gene clusters. In addition, 10 and 4 of 19 isolates of Alternaria brassicicola recovered from cabbage and radish seed were resistant to fludioxonil at 1.0 and $100 \mathrm{mg} /$ liter, respectively (Iacomi-Vasilescu et al. 2004). 
These isolates had not been exposed to fludioxonil; the authors hypothesized that the isolates were cross-resistant to fludioxonil, because they also were resistant to the dicarboximide fungicides iprodione and procymidone.

Some cucurbits that must be sprayed to manage gummy stem blight, such as muskmelon and cucumber (C. sativus L.), are harvested every 1 to 2 days (Anonymous 2007; Keinath et al. 2007). Cyprodinilfludioxonil is particularly useful during the cucurbit harvest period, because the preharvest interval (i.e., the time after application before treated fruit may be harvested) is only 1 day. In contrast, fungicides in FRAC group 3, such as tebuconazole and difenoconazole, have a 7-day preharvest interval on cucurbits. Thus, it is likely that cyprodinil-fludioxonil will be applied late in the season when disease severity and the local field population of $D$. bryoniae are great (Keinath 2000, 2014). This use pattern, which is dictated by the frequent harvest schedule for cucurbits and the need to rotate fungicides, is contrary to one fungicide resistance management guideline that recommends that fungicides with a risk of resistance should be applied early in the growing season or epidemic (Staub 1991). In addition, cyprodinilfludioxonil reduced gummy stem blight severity on watermelon seedlings in the greenhouse (Keinath 2013). Greenhouse use may increase the risk of fungicide resistance developing in the target pathogen (Keinath 2009; Stevenson et al. 2004).

Cyprodinil is rated as having a medium risk, and fludioxonil has a low to medium risk of resistance development (Fungicide Resistance Action Committee 2015). Thus, it would be useful to know the baseline sensitivity to cyprodinil and fludioxonil, so that any future decreases in sensitivity could be determined accurately. Baseline sensitivities to cyprodinil and fludioxonil have not been determined for D. bryoniae. The objectives of this study were to (i) evaluate a representative collection of isolates of D. bryoniae that never were exposed to cyprodinil and fludioxonil for sensitivity to these fungicides and (ii) determine the efficacy of two cyprodinil-containing fungicides against gummy stem blight caused by isolates resistant to quinone-outsideinhibitor (QoI) (FRAC group 11) and succinate-dehyrogenaseinhibitor (SDHI) (FRAC group 7) fungicides.

\section{Materials and Methods}

Isolates. For this study, 146 isolates of D. bryoniae were selected from an extensive, existing culture collection. Isolates for the baseline study were collected between 1994 and 2008 to preclude exposure to cyprodinil and fludioxonil (Keinath 2009; Keinath and Hansen 2013). Isolates had been recovered primarily from watermelon (107 isolates) and also cucumber (18 isolates) and muskmelon (21 isolates). Each isolate originated from a leaf or seedling, except that two isolates from cucumber came from fruit. Isolates were collected in South Carolina (101 isolates) and other states (45 isolates), including Indiana (4 isolates), Maryland (3 isolates), Delaware (4 isolates), Georgia (6 isolates), Florida (9 isolates), Texas (6 isolates), and California (13 isolates). Isolates from other states were collected between 1996 and 2001, and isolates from South Carolina were collected between 1994 and 2008. A majority of the isolates came from fields (105 isolates in 20 samples), and 41 isolates in 11 samples came from seedlings grown in greenhouses. In all, 11 greenhouse isolates were recovered from seedlings grown from seed that was produced in the People's Republic of China (5 isolates) or Thailand (6 isolates) (Keinath and Hansen 2013; Kothera et al. 2003). (The origin of the seed that produced diseased seedlings in the remaining nine samples from greenhouses was unknown.) Isolates were stored on dried filter paper at $5^{\circ} \mathrm{C}$.

Fungicide sensitivity. Cyprodinil (99\% technical grade) and fludioxonil (98\% technical grade) (supplied by Syngenta Crop Protection) were dissolved in acetone and ethanol, respectively, to make stock solutions of 2.0 and $10.0 \mathrm{mg} /$ liter (Baroffio et al. 2003; Hilber and Schüepp 1996). Aliquots of the stock solutions were added to autoclaved glucose minimal medium cooled to $54^{\circ} \mathrm{C}$ to yield concentrations of each fungicide of $0.01,0.1,1.0$, and $10.0 \mathrm{mg} /$ liter and dispensed into $15-\mathrm{mm}$ petri dishes (Myresiotis et al. 2007). Each liter of fungicide-amended medium received additional solvent to bring the final concentration to $1.0 \mathrm{ml} /$ liter. Control media received only solvent at $1.0 \mathrm{ml} / \mathrm{liter}$.
Isolates of $D$. bryoniae were grown from a piece of dried filter paper $(0.5$ by $0.5 \mathrm{~cm})$ onto one-quarter-strength potato dextrose agar in petri dishes that were not sealed with Parafilm and held at 23 to $25^{\circ} \mathrm{C}$ with a 16-h photoperiod for 5 days. Agar plugs ( $7 \mathrm{~mm}$ in diameter) were cut from the edges of source cultures and placed onto fungicide-amended media that were incubated at 23 to $25^{\circ} \mathrm{C}$ with a 16-h photoperiod. After 5 days of growth, two perpendicular colony diameters per plate were measured and averaged. The diameter of the agar plug was subtracted from the colony diameters before calculating the means. Relative colony diameter was calculated by dividing the mean colony diameter on each fungicide-amended plate by the mean colony diameter across the two nonamended plates for each isolate (Keinath and Hansen 2013). Two replicate plates were used per test, and isolates were tested twice in repeated trials. Within each trial, 6 to 12 isolates were tested at one time.

Fungicide efficacy in the field. A fungicide containing $37.5 \%$ cyprodinil plus 25.0\% fludioxonil (Switch 62.5WG; Syngenta Crop Protection) and one containing $24.1 \%$ cyprodinil plus $8.4 \%$ difenoconazole (Inspire Super 2.82EW) were evaluated for control of gummy stem blight caused by isolates resistant to QoI and SDHI fungicides. The experiments were done at the Clemson University Coastal Research and Education Center in Charleston, SC $\left(32^{\circ} 47^{\prime}\right.$ $30.4 \mathrm{~N} ; 80^{\circ} 4^{\prime} 11.16 \mathrm{~W}$ ) in fall 2008, 2009, and 2011. The soil type in all three fields was Yonges loamy fine sand (fine-loamy, mixed, active, thermic Typic Endoaqualfs) with $\mathrm{pH}$ values of 6.2, 7.1, and 6.0 , respectively. The fields were cropped to watermelon, various cucurbits, and rye mixed with white clover in autumn 2007, 2008, and 2010, respectively; all three fields were fallow in spring.

Fertilizer $(10 \mathrm{~N}-10 \mathrm{P}-10 \mathrm{~K}$ at $673 \mathrm{~kg} / \mathrm{ha})$ was broadcast over the rows, and beds were cultivated lightly with a rotovator, shaped $0.46 \mathrm{~m}$ wide on $1.8 \mathrm{-m}$ centers, and covered with white-on-black polyethylene mulch. Watermelon 'Royal Star' seedlings (2 to 3 weeks old; Syngenta Seeds, Greensboro, NC) were transplanted into every other row on 31 July 2008, 21 July 2009, and 15 August 2011. Seedlings were spaced $0.61 \mathrm{~m}$ apart in 2008 and 2009 to yield 15 plants per plot and $0.91 \mathrm{~m}$ apart in 2011 to yield 10 plants per plot. Plots were arranged in a randomized complete block design with four replications. Plots were one row wide and $9.1 \mathrm{~m}$ long. Plots were separated within rows by $0.9,1.5$, and $3.0 \mathrm{~m}$ of planted space in 2008 , 2009 , and 2011, respectively. Liquid 8N-0P-8K fertilizer was applied to the field throughout the season through the drip irrigation system. The $\mathrm{N}$ and $\mathrm{K}$ rates changed with plant growth stage: $15 \mathrm{~kg}$ of $\mathrm{N}$ and $\mathrm{K}$ per week from transplanting to blossoming, $23 \mathrm{~kg} /$ week from blossoming to fruit set, $31 \mathrm{~kg} /$ week from fruit set to first harvest, and $23 \mathrm{~kg} /$ week after first harvest. On 17 August 2011, mefenoxam (Ridomil Gold 480EC) was applied at $1.1 \mathrm{~kg}$ per treated hectare through the drip irrigation system to prevent Pythium damping-off of transplants. Standard herbicides recommended for cucurbits were applied, and insecticides were applied based on insects detected in the fields (Keinath and DuBose 2009; Keinath et al. 2010, 2012). Fungicides with specific activity against powdery mildew, including quinoxyfen, myclobutanil, or triflumizole, and downy mildew, including cymoxanil-famoxadone, propamocarb, fluopicolide, or cyazofamid, were applied at labeled rates to prevent and manage these two diseases each year (Keinath and DuBose 2009; Keinath et al. 2010, 2012). Thiophanate-methyl was applied at $0.39 \mathrm{~kg} / \mathrm{ha}$ on 3 and 17 September 2009 after anthracnose was detected in several nontreated control plots.

To ensure that severe gummy stem blight developed, plants were inoculated with a conidial suspension of two or more isolates of D. bryoniae from South Carolina that included isolates resistant to pyraclostrobin and boscalid. On 18 August 2008, plants within rows between plots were inoculated with $D$. bryoniae isolates HD10 (resistant to pyraclostrobin and boscalid, recovered from watermelon) and C154B-R (sensitive to both fungicides, recovered from muskmelon) at $5 \times 10^{5}$ conidia/ml. On 13 August 2009, plants within rows between plots were inoculated with isolates HD10, W493 (resistant to pyraclostrobin, recovered from watermelon), C200 (sensitive to both fungicides, recovered from muskmelon), and C154B-R at $5 \times 10^{5}$ conidia/ml. On 13 September 2009 , the plant in the center of each plot also was inoculated with the same isolates. On 5 
September 2011, one plant between plots was inoculated with two pyraclostrobin- and boscalid-resistant isolates, D. bryoniae HD10 and W764 (recovered from watermelon), at $10^{6}$ conidia/ml. On 22 September 2011, the plant in the center of each plot was inoculated with the same isolates. To ensure that leaves were wet to promote infection, overhead, low-pressure, mini-wobbler sprinklers (Senninger Irrigation, Clermont, FL) were used to produce a mist for $10 \mathrm{~min}$ in the evening at 7:00 and 11:00 P.M. from 18 August 2008 through the end of September 2008. In 2009, sprinklers were operated for $10 \mathrm{~min}$ at 7:00 A.M. and 11:00 P.M. from 30 July through 29 September; the morning mist period was omitted on dates when any pesticides were applied. In 2011, plants were misted for $30 \mathrm{~min}$ at 11:00 P.M. from 5 September until mid-October.

In each year, fungicides were applied every 7 days, beginning 20 August 2008, 11 August 2009, and 1 September 2011, for a total of seven applications in each treatment (Table 1). Fungicides were applied in a volume of 46 liters/ha with a $\mathrm{CO}_{2}$-backpack sprayer operated at 414 newton $/ \mathrm{m}^{2}$ and fitted with three TeeJet TX 26 nozzles (Spraying Systems Co., Wheaton, IL), orifice size $2.35 \mathrm{~cm}$, spaced $45 \mathrm{~cm}$ apart. Fungicide applications began before symptoms of gummy stem blight were detected in any plot. Boscalid-pyraclostrobin, cyprodinilfludioxonil, and cyprodinil-difenoconazole were applied in alternation with chlorothalonil because of label restrictions on the numbers of sequential and total applications (Table 1). Tebuconazole (plus Induce adjuvant blend at $0.06 \%$ [vol/vol]) also was applied in alternation with chlorothalonil, so that this treatment could be compared in a similar manner to the other fungicide treatments. Chlorothalonil was applied alone in an additional treatment. Water was applied to the control treatment that did not receive fungicides.

Gummy stem blight severity on leaves was rated as percent leaf surface area symptomatic with a 16-point Horsfall-Barratt-type scale $(0=0,1=0$ to $2,2=2$ to $7,3=7$ to $13,4=13$ to $21,5=21$ to $30,6=$ 30 to $40,7=40$ to $50,8=50$ to $60,9=60$ to $70,10=70$ to $79,11=79$ to $87,12=87$ to $93,13=93$ to $98,14=98$ to 99 , and $15=100 \%$ ) six times each year between 30 and 75 days after transplanting. Marketable-sized fruit ( $\geq 4.5 \mathrm{~kg}$ each for seeded watermelon) were harvested, counted, and weighed on 2 and 10 October 2008, 14 and 21 September 2009, and 20 October and 1 November 2011.

Data analysis. Plots of relative colony diameter against the base-10 logarithm of fungicide concentration were not linear for most isolates. Thus, relative colony diameter was probit-transformed. To calculate effective concentration (EC) values that reduced relative colony diameter by $50 \%\left(\mathrm{EC}_{50}\right)$ and $90 \%\left(\mathrm{EC}_{90}\right)$, probit-transformed relative colony diameter was regressed against the base-10 logarithm of three concentrations of each fungicide concentration using PROC GLM of SAS (SAS version 9.3; SAS, Inc., Cary, NC) (Keinath 2009; Stevenson et al. 2004). The $10.0 \mathrm{mg} /$ liter concentration for each fungicide was not included to ensure that all plots were linear. The resulting linear regression equations for each isolate-fungicide combination were solved to calculate $\mathrm{EC}_{50}$ and $\mathrm{EC}_{90}$ values. Frequency distributions were determined using SAS PROC UNIVARIATE with the Shapiro-Wilk W statistic and SigmaPlot 12.5 (Systat Software, Inc., San Jose, CA). To compare $\mathrm{EC}_{50}$ and $\mathrm{EC}_{90}$ values among groups of isolates, EC values were transformed by calculating the base-10 logarithm to reduce nonnormality. Means among isolates grouped by origin (field or greenhouse), location (South Carolina or other states), or host (Citrullus or Cucumis spp.) were compared with one-way analysis of variance (SAS PROC MIXED).

Severity ratings for fungicide evaluations in the field were converted to the midpoint of the percentage range associated with each rating. Area under the disease progress curve (AUDPC) was calculated from six percentage severity ratings each year, collected between 29 August and 13 October 2008, 21 August and 7 October 2009, and 26 September and 31 October 2011 (Shaner and Finney 1977). Disease and yield data were analyzed with a mixed-model maximum likelihood analysis (PROC MIXED) with a split-plot model, with year (whole plot), treatment (subplot), and the yeartreatment interaction as fixed effects and block within year as a random effect. Before analysis, severity percentages were transformed with arcsine of the square root, and AUDPC values were transformed with the base-10 logarithm to correct for nonnormality and inequality of variances among treatments. Residuals from analyses of variance were checked for nonnormality and inequality of variance with PROC UNIVARIATE. Back-transformed leastsquares means are shown in the tables. Treatment means were compared with $t$ tests.

\section{Results}

Isolate growth on fungicide-amended media. Colony diameters of 14 isolates were measured after 5 and 7 days of growth to determine the optimum time interval for measurements before colonies on nonamended media reached the edges of the plates. Relative colony diameters for $0.01,0.10$, and $1.0 \mathrm{mg} /$ liter did not differ significantly when calculated after 5 or 7 days of growth, and there were no interactions of day with isolate, fungicide, or concentration (data not shown). Five days was selected for all experiments.

Colony diameters on nonamended media differed by location where isolates were collected. Isolates collected in South Carolina had larger colonies (mean of $4.2 \pm 0.07 \mathrm{~cm}$ ) than isolates collected in other states $(3.9 \pm 0.11 \mathrm{~cm})$ when grown on media amended with ethanol $(P=0.02)$. A similar difference was observed on media amended with acetone: $4.3 \pm 0.07 \mathrm{~cm}$ compared with $3.9 \pm$ $0.10 \mathrm{~cm}(P=0.004)$. The year of collection did not affect colony diameter (data not shown).

Mean colony diameters of $146 \mathrm{D}$. bryoniae isolates were $4.15 \pm$ $0.021 \mathrm{~cm}$ when grown on media amended with ethanol alone and

Table 1. Fungicides applied to field-grown watermelon inoculated with Didymella bryoniae in three autumn growing seasons in Charleston, SC

\begin{tabular}{|c|c|c|c|c|c|c|c|}
\hline \multirow[b]{3}{*}{ Fungicide common name (trade name, formulation) ${ }^{\mathrm{v}}$} & \multirow[b]{3}{*}{ Rate $(\mathrm{kg} / \mathrm{ha})$} & \multicolumn{6}{|c|}{ Number of applications ${ }^{\mathbf{u}}$} \\
\hline & & \multicolumn{2}{|c|}{2008} & \multicolumn{2}{|c|}{2009} & \multicolumn{2}{|c|}{2011} \\
\hline & & $\bar{N}$ & $\overline{\text { Chlo }}$ & $\bar{N}$ & $\overline{\text { Chlo }}$ & $N$ & Chlo \\
\hline Boscalid-pyraclostrobin (Pristine 38WG) & 0.40 & 3 & 4 & 4 & 3 & n.d. & n.d. \\
\hline Chlorothalonil (Bravo Weather Stik 6SC) & 1.68 & 7 & n.a. & 7 & n.a. & 7 & n.a. \\
\hline Tebuconazole (Folicur 3.6F) & 0.25 & $5^{\mathrm{w}}$ & $2^{\mathrm{w}}$ & $5^{\mathrm{x}}$ & $2^{\mathrm{x}}$ & n.d. & n.d. \\
\hline Cyprodinil-difenoconazole (Inspire Super 2.82SC & 0.49 & $5^{\mathrm{x}}$ & $2^{\mathrm{x}}$ & $5^{\mathrm{x}}$ & $2^{x}$ & $4^{y}$ & $3^{y}$ \\
\hline Cyprodinil-fludioxonil (Switch 62.5WG) & 0.61 & $5^{\mathrm{x}}$ & $2^{\mathrm{x}}$ & $5^{\mathrm{x}}$ & $2^{\mathrm{x}}$ & $3^{z}$ & $4^{\mathrm{z}}$ \\
\hline \multirow{2}{*}{\multicolumn{8}{|c|}{$\begin{array}{l}\text { u Number of applications }(N) \text { and number with chlorothalonil (Chlo); n.d. = not done (treatment not included in 2011) and n.a. = not applicable (no rotation with } \\
\text { chlorothalonil). } \\
\text { v When rotated with chlorothalonil, the fungicide listed in the first column was applied first. except in 2011, as noted below. }\end{array}$}} \\
\hline & & & & & & & \\
\hline \multicolumn{8}{|c|}{$\begin{array}{l}\text { w In } 2008 \text {, two applications of tebuconazole were followed by one application of chlorothalonil, and then three applications of tebuconazole were followed by one } \\
\text { application of chlorothalonil. }\end{array}$} \\
\hline \multicolumn{8}{|c|}{$\begin{array}{l}\text { Two applications of the listed fungicide followed by one application of chlorothalonil were made twice, then one application of the listed fungicide was followed } \\
\text { by one application of chlorothalonil. }\end{array}$} \\
\hline \multicolumn{8}{|c|}{ y In 2011, chlorothalonil was applied three times in succession, followed by four applications of cyprodinil-difenoconazole instead of alternating applications as } \\
\hline
\end{tabular}


$4.20 \pm 0.021 \mathrm{~cm}$ on media amended with fludioxonil at $0.01 \mathrm{mg} / \mathrm{liter}$ dissolved in ethanol. Means did not differ significantly $(P=0.08)$, and there was no isolate-concentration interaction $(P=0.84)$. Mean relative colony diameter was smaller when isolates were grown on media amended with fludioxonil at $1.0 \mathrm{mg} / \mathrm{liter}(3.6 \pm 0.006 \%$ of the diameter of the nonamended control) than on media amended with $0.10 \mathrm{mg} / \mathrm{liter}(25.4 \pm 0.007 \%)(P<0.0001)$.

Mean colony diameters of $D$. bryoniae isolates were slightly smaller on media amended with cyprodinil at $0.01 \mathrm{mg} / \mathrm{liter}(4.00 \pm 0.021 \mathrm{~cm})$ compared with control media amended only with acetone $(4.18 \pm$ $0.021 \mathrm{~cm})(P<0.0001)$. There was no isolate-concentration interaction $(P=0.23)$. Mean relative colony diameters also differed between 0.10 and $1.00 \mathrm{mg} /$ liter cyprodinil but the isolate-concentration interaction was significant $(P<0.0001)$.

Concentrations of cyprodinil and fludioxonil of $10.0 \mathrm{mg} / \mathrm{liter}$ were tested once on 24 isolates from watermelon collected from various locations within South Carolina. None of the isolates grew with cyprodinil at $10.0 \mathrm{mg} / \mathrm{liter}$, and 6 of the 24 isolates grew with fludioxonil at $10.0 \mathrm{mg} / \mathrm{liter}$. In a second trial with fludioxonil at $10.0 \mathrm{mg} / \mathrm{liter}$, 11 of 12 isolates had slight growth. With these 36 isolates, mean colony diameter with fludioxonil at $10 \mathrm{mg} / \mathrm{liter}(0.11 \pm 0.028 \mathrm{~cm}) \mathrm{did}$ not differ from colony diameter at $1.0 \mathrm{mg} / \mathrm{liter}(0.14 \pm 0.028 \mathrm{~cm})$ $(P=0.37)$, and there was no concentration-isolate interaction $(P=$ $0.27)$. Only 3 of the 36 isolates had a mean colony diameter $>0$ ( $t$ tests, $P \leq 0.05)$. Thus, the remaining 110 isolates were not tested on media amended with fludioxonil at $10.0 \mathrm{mg} /$ liter.

$\mathbf{E C}_{\mathbf{5 0}}$ and $\mathbf{E C}_{\mathbf{9 0}}$ values for cyprodinil and fludioxonil. All 146 isolates of $D$. bryoniae included in this study were sensitive to both cyprodinil and fludioxonil. Mean $\mathrm{EC}_{50}$ values were approximately 0.05 and $0.10 \mathrm{mg} /$ liter, respectively. The mean, median, and maximum $\mathrm{EC}_{50}$ values for cyprodinil were approximately half of the corresponding values for fludioxonil (Table 2). Consequently, the resistance factor (i.e., the maximum $\mathrm{EC}_{50}$ value divided by the minimum $\mathrm{EC}_{50}$ value) also was approximately half as large for cyprodinil (5.1) as for fludioxonil (9.4) (Table 2) (Gisi et al. 1997). The $\mathrm{EC}_{90}$ values for cyprodinil and fludioxonil were approximately three and four times greater, respectively, than the $\mathrm{EC}_{50}$ values for the two fungicides (Table 2). Only one isolate, RA3, which had been recovered from watermelon in Florida in 1997, had an $\mathrm{EC}_{90}$ value of fludioxonil greater than $1.0 \mathrm{mg} /$ liter (the $\mathrm{EC}_{90}$ maximum shown in Table 2).

The ranges of $\mathrm{EC}_{50}$ and $\mathrm{EC}_{90}$ values were narrower for cyprodinil than for fludioxonil (Table 2; Figs. 1 and 2). Resistance factors did not differ appreciably between $\mathrm{EC}_{50}$ and $\mathrm{EC}_{90}$ values within fungicides. The distribution of $\mathrm{EC}_{50}$ and $\mathrm{EC}_{90}$ values for both fungicides was nonnormal for the 146 isolates, because a small number of isolates were less sensitive (i.e., had higher EC values) than the bulk of the sampled population (Figs. 1 and 2). Log-transformed $\mathrm{EC}_{50}$ values for cyprodinil were normally distributed (Shapiro-Wilk W $=0.99$, $P=0.43$ ) but a logarithmic transformation of $\mathrm{EC}_{50}$ values for fludioxonil or $\mathrm{EC}_{90}$ values for both fungicides did not change the distribution.

Means of $\mathrm{EC}_{50}$ values for the two fungicides were calculated and compared for three subgroups of isolates (Tables 3 and 4). $\mathrm{EC}_{50}$ values differed by geographic location for both fungicides. Mean $\mathrm{EC}_{50}$ values were slightly greater for both fungicides for isolates from states other than South Carolina than for isolates from South Carolina ( $P=0.01$ for cyprodinil and $P=0.03$ for fludioxonil). $\mathrm{EC}_{50}$ values did not differ when isolates were classified by host genus (Citrullus or Cucumis) or by environment from which they were obtained (field or greenhouse) (Table 4).

Field efficacy of cyprodinil-containing fungicides. Mean severity of gummy stem blight on plants not receiving a fungicide treatment was $>75 \%$ at 60 to 64 days after transplanting in all 3 years (Table 5). In all three experiments, cyprodinil-fludioxonil, cyprodinildifenoconazole, or tebuconazole alternated with chlorothalonil and chlorothalonil applied alone reduced severity of gummy stem blight and AUDPC by 35 to $91 \%$ when compared with the water control treatment (Table 5). Disease severity on plants treated with boscalidpyraclostrobin alternated with chlorothalonil was not significantly different from the water control treatment in 2008 or 2009, and AUDPC for these two treatments also did not differ (Table 5; boscalidpyraclostrobin was not tested in 2011). The largest differences between fungicide treatments and the water control treatment were observed in 2011. The year-treatment interactions were significant when data from all 3 years were combined $(P=0.0015$ and 0.002 for severity and AUDPC, respectively). Year-treatment interactions also were significant when data from 2 years were combined, except for AUDPC from 2008 and 2011 (data not shown).

Disease severity and AUDPC for boscalid-pyraclostrobin alternated with chlorothalonil did not differ from disease severity and AUDPC for the chlorothalonil treatment in both years tested (2008 and 2009; Table 5). In 2008 and 2009, disease was less severe with cyprodinil-fludioxonil alternated with chlorothalonil than with boscalid-pyraclostrobin alternated with chlorothalonil $(P \leq 0.05)$. In 2008, disease severity and AUDPC values also were less with cyprodinil-difenoconazole or tebuconazole alternated with chlorothalonil than with boscalid-pyraclostrobin alternated with chlorothalonil.

In 2008 and 2011, gummy stem blight at 60 to 64 days after transplanting was less severe on watermelon treated with either cyprodinilfludioxonil or cyprodinil-difenoconazole alternated with chlorothalonil compared with chlorothalonil alone $(P \leq 0.05)$ (Table 5). Disease severity on plants treated with tebuconazole alternated with chlorothalonil did not differ from severity on plants treated with chlorothalonil. In 2008, AUDPC was less for the treatments with cyprodinil-fludioxonil, cyprodinil-difenoconazole, or tebuconazole alternated with chlorothalonil than for chlorothalonil alone; the two cyprodinil treatments had lower AUDPC values than the tebuconazole treatment. In 2011, AUDPC for cyprodinil-fludioxonil alternated with chlorothalonil also was less than the AUDPC for chlorothalonil. The cyprodinil and tebuconazole treatments did not differ from chlorothalonil alone in 2009 (Table 5). The total and marketable weights and numbers of fruit did not differ significantly among any treatments in any experiment (data not shown).

\section{Discussion}

The mean baseline $\mathrm{EC}_{50}$ for cyprodinil for $146 \mathrm{D}$. bryoniae isolates never exposed to the fungicide was $0.052 \mathrm{mg} / \mathrm{liter}$. This value was seven times higher than the baseline $\mathrm{EC}_{50}$ determined for isolates of $B$. cinerea collected from nonsprayed, symptomatic strawberry fruit in Switzerland (Hilber and Schüepp 1996). The value for D. bryoniae was 17 times higher than the lowest $\mathrm{EC}_{50}$ values obtained for isolates of $B$. cinerea collected from greenhouse-grown tomato, eggplant, and cucumber in Greece 7 years after cyprodinil-fludioxonil was first used in the area (Myresiotis et al. 2007). However, the resistance factors for the $B$. cinerea and $D$. bryoniae populations were similar at $2.8,3.3$, and

Table 2. Effective concentration (EC) that reduced relative colony diameter by 50 and $90 \%\left(\mathrm{EC}_{50}\right.$ and $\mathrm{EC}_{90}$, respectively) values for 146 isolates of Didymella bryoniae grown on glucose minimal medium amended with cyprodinil or fludioxonil ${ }^{\mathrm{x}}$

\begin{tabular}{lccccccccr}
\hline Fungicide & EC & Mean & SD & Median & Min & Max & Range & RF $^{\mathbf{y}}$ & ${\text { Normality }(P r>W)^{\mathbf{z}}}$ \\
\hline Cyprodinil & $\mathrm{EC}_{50}$ & 0.052 & 0.016 & 0.050 & 0.020 & 0.103 & 0.083 & 5.1 & 0.0085 \\
Cyprodinil & $\mathrm{EC}_{90}$ & 0.176 & 0.047 & 0.168 & 0.083 & 0.413 & 0.330 & 5.0 & $<0.0001$ \\
Fludioxonil & $\mathrm{EC}_{50}$ & 0.099 & 0.038 & 0.094 & 0.025 & 0.234 & 0.209 & 9.4 & $<0.0001$ \\
Fludioxonil & $\mathrm{EC}_{90}$ & 0.407 & 0.170 & 0.359 & 0.132 & 1.075 & 0.943 & 8.1 & $<0.0001$ \\
\hline
\end{tabular}

$\mathrm{x} \mathrm{SD}=$ standard deviation, $\mathrm{Min}=$ minimum, and $\mathrm{Max}=$ maximum.

y Resistance factor $(\mathrm{RF})=$ maximum $\mathrm{EC}_{50}$ divided by minimum $\mathrm{EC}_{50}$ (Gisi et al. 1997).

${ }^{\mathrm{z}}$ Probability of a greater Shapiro-Wilk $W$ factor, a measure of normality. 
5.2, respectively (Myresiotis et al. 2007). The narrow ranges of sensitivity are consistent with the existence of one gene controlling sensitivity to cyprodinil.

Different researchers use different thresholds for classifying fungal pathogens according to their sensitivity to cyprodinil. In Europe, a threshold of $0.03 \mathrm{mg} /$ liter was used whereas, in the United States, thresholds of 0.10 or $5.0 \mathrm{mg} / \mathrm{liter}$ have been used (Amiri et al. 2013; Baroffio et al. 2003; Fernández-Ortuño et al. 2013; Hilber and Schüepp 1996; Leroch et al. 2013). B. cinerea is considerably more

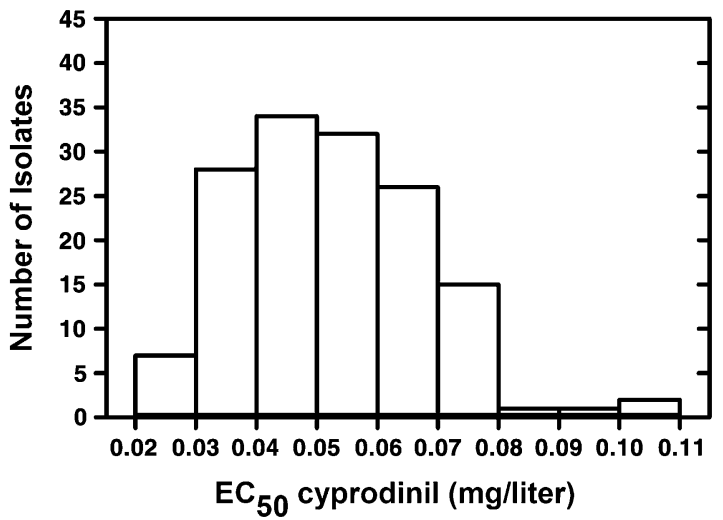

Fig. 1. Nonnormal frequency distribution of cyprodinil concentrations (mg/liter) that inhibited growth of 146 isolates of Didymella bryoniae by $50 \%\left(\mathrm{EC}_{50}\right)$.

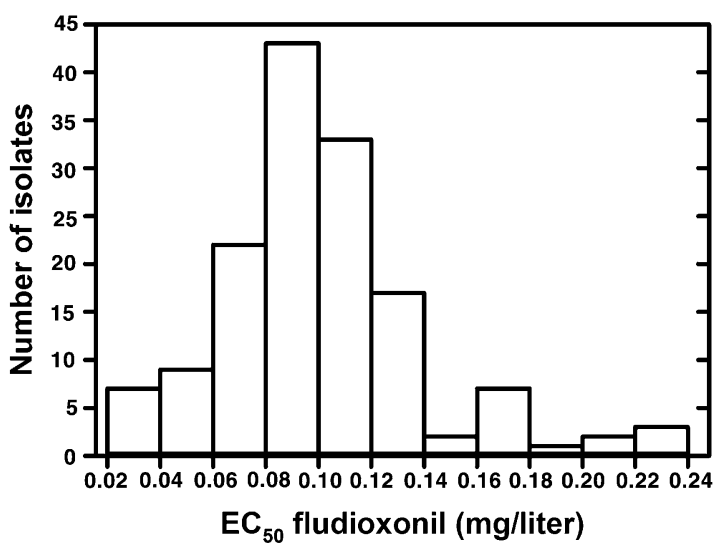

Fig. 2. Nonnormal frequency distribution of fludioxonil concentrations (mg/liter) that inhibited growth of 146 isolates of Didymella bryoniae by $50 \%\left(\mathrm{EC}_{50}\right)$. sensitive to cyprodinil than $D$. bryoniae; therefore, a threshold of $0.03 \mathrm{mg} / \mathrm{liter}$ is inappropriate for D. bryoniae. Because the maximum $\mathrm{EC}_{50}$ for an individual isolate of $D$. bryoniae was cyprodinil at $0.103 \mathrm{mg} / \mathrm{liter}$, and colony diameters were noticeably smaller on medium amended with cyprodinil at $0.1 \mathrm{mg} / \mathrm{liter}$ than on control medium, $0.1 \mathrm{mg} /$ liter is suggested as a discriminatory dose that can be used to rapidly identify $D$. bryoniae with reduced sensitivity to cyprodinil in future samplings.

The baseline $\mathrm{EC}_{50}$ for fludioxonil was $0.099 \mathrm{mg} / \mathrm{liter}$ for 146 D. bryoniae isolates never exposed to the fungicide. This baseline was 4 and 198 times greater, respectively, than the baseline $\mathrm{EC}_{50}$ values determined for $P$. expansum $(0.02 \mathrm{mg} / \mathrm{liter})$ and $B$. cinerea $(0.005 \mathrm{mg} /$ liter) from apple in Washington State $(\mathrm{Li}$ and Xiao 2008; Zhao et al. 2010). The baseline also was 12.4 times higher than $\mathrm{EC}_{50}$ values for sensitive $B$. cinerea isolates in populations previously exposed to fludioxonil in Greece (Myresiotis et al. 2007). However, the resistance factor for D. bryoniae (9.4) was similar to those for P. expansum (6.2) and B. cinerea (12.7) (Li and Xiao 2008; Zhao et al. 2010). Most researchers have used fludioxonil at $0.1 \mathrm{mg} /$ liter as the threshold for determining whether an isolate of B. cinerea is sensitive or resistant, although Zhao et al. (2010) used $0.038 \mathrm{mg} /$ liter and Leroch et al. (2013) used spore germination at 0.2 and $1.0 \mathrm{mg} /$ liter (Amiri et al. 2013; Baroffio et al. 2003; FernándezOrtuño et al. 2013; Myresiotis et al. 2007). For other fungal pathogens, thresholds ranged from $0.13 \mathrm{mg} /$ liter for $P$. digitatum to $2 \mathrm{mg} / \mathrm{liter}$ for A. brassicicola (Iacomi-Vasilescu et al. 2004; Kanetis et al. 2010). Because fludioxonil at $0.1 \mathrm{mg} / \mathrm{liter}$ was close to the mean and median values for 146 isolates of $D$. bryoniae, the discriminatory dose for future studies should be approximately $0.25 \mathrm{mg} / \mathrm{liter}$, slightly above the maximum $\mathrm{EC}_{50}$ value for an individual isolate.

The relatively small ranges and resistance factors for cyprodinil and fludioxonil for isolates of $D$. bryoniae that never were exposed to these fungicides was similar to the ranges (0.03 to 0.25$)$ and resistance factors (2.7 to 14.2) for D. bryoniae isolates never exposed to boscalid or difenoconazole (Keinath 2009; Keinath and Hansen 2013; Thomas et al. 2012b). The ranges for baseline isolates from South Carolina and other states tested for sensitivity to azoxystrobin and tebuconazole were 10 and 19 times greater, respectively, than the range for cyprodinil (Keinath 2008; Keinath and Hansen 2013). The resistance factor for azoxystrobin (165) was considerably higher than the values of $<10$ for cyprodinil and fludioxonil (Keinath 2008).

In the field, substituting cyprodinil-fludioxonil or cyprodinildifenoconazole for over half of the applications of chlorothalonil in the chlorothalonil-alone spray program improved control of gummy stem blight in 2 of 3 years. Although tebuconazole rotated with chlorothalonil also was more effective than chlorothalonil applied alone in 2008, when five applications of tebuconazole were made, the maximum number of tebuconazole applications is limited to three at the

Table 3. Effective concentration (EC) that reduced relative colony diameter by $50 \%\left(\mathrm{EC}_{50}\right)$ values for 146 isolates of Didymella bryoniae grown on glucose minimal medium amended with cyprodinil and grouped by geographic, host, and environmental origins ${ }^{\mathrm{w}}$

\begin{tabular}{|c|c|c|c|c|c|c|c|c|c|}
\hline Group & $N$ & Mean & SD & Median & Min & $\operatorname{Max}$ & Range & $\mathbf{R F}^{\mathbf{x}}$ & Normality $(\operatorname{Pr}>W)^{\mathbf{y}}$ \\
\hline \multicolumn{10}{|l|}{ State } \\
\hline South Carolina & 101 & 0.050 & 0.015 & 0.048 & 0.020 & 0.099 & 0.079 & 5.0 & 0.152 \\
\hline Other states & 45 & 0.057 & 0.016 & 0.054 & 0.029 & 0.103 & 0.074 & 3.6 & 0.031 \\
\hline$P$ value ${ }^{\mathrm{z}}$ & $\ldots$ & 0.011 & $\ldots$ & $\ldots$ & $\ldots$ & $\ldots$ & $\ldots$ & $\ldots$ & $\ldots$ \\
\hline \multicolumn{10}{|l|}{ Host } \\
\hline Citrullus & 107 & 0.052 & 0.016 & 0.050 & 0.020 & 0.103 & 0.083 & 5.2 & 0.002 \\
\hline Cucumis & 39 & 0.054 & 0.012 & 0.054 & 0.028 & 0.078 & 0.050 & 2.8 & 0.532 \\
\hline$P$ value $\mathrm{z}$ & $\ldots$ & 0.203 & $\ldots$ & $\ldots$ & $\ldots$ & $\ldots$ & $\ldots$ & $\ldots$ & $\ldots$ \\
\hline \multicolumn{10}{|l|}{ Environment } \\
\hline Field & 105 & 0.051 & 0.015 & 0.050 & 0.020 & 0.099 & 0.079 & 5.0 & 0.399 \\
\hline Greenhouse & 41 & 0.055 & 0.017 & 0.051 & 0.030 & 0.103 & 0.070 & 3.4 & 0.006 \\
\hline$P$ value $^{\mathrm{z}}$ & $\cdots$ & 0.213 & $\cdots$ & $\cdots$ & $\cdots$ & $\cdots$ & $\cdots$ & $\cdots$ & $\cdots$ \\
\hline
\end{tabular}

${ }^{\mathrm{w}} \mathrm{SD}=$ standard deviation, $\mathrm{Min}=$ minimum, and $\mathrm{Max}=$ maximum.

${ }^{x}$ Resistance factor $(\mathrm{RF})=$ maximum $\mathrm{EC}_{50}$ divided by minimum $\mathrm{EC}_{50}$ (Gisi et al. 1997).

y Probability of a greater Shapiro-Wilk $W$ factor, a measure of normality.

${ }^{\mathrm{z}}$ Probability that the means for the two groups immediately above do not differ, $F$ test from one-way analysis of variance. 
$0.25 \mathrm{~kg} / \mathrm{ha}$ rate. If tebuconazole had been applied only three times, is it likely that the efficacy of tebuconazole rotated with chlorothalonil would not have differed from chlorothalonil applied alone, as reported previously (Keinath et al. 2001). Cyprodinil-difenoconazole and cyprodinil-fludioxonil also were more effective than boscalidpyraclostrobin in reducing the severity of foliar blight caused by isolates of $D$. bryoniae resistant to boscalid and pyraclostrobin. Although five applications of cyprodinil-containing fungicides were made in 2008 and 2009, and three or four applications were made in 2011, the different numbers of applications did not correspond to the relative rankings of disease severity or AUDPC for the 3 years (Table 5). Similarly, in Georgia, seven applications of cyprodinilfludioxonil or cyprodinil-difenoconazole were more effective than chlorothalonil or boscalid-pyraclostrobin, and efficacy of tebuconazole was not significantly different from cyprodinil-fludioxonil, cyprodinil-difenoconazole, or chlorothalonil (Sanders and Langston 2013). In the greenhouse, cyprodinil applied alone and cyprodinilfludioxonil reduced incidence and severity of gummy stem blight on watermelon seedlings (Keinath 2013). In the same study, difenoconazole was more effective than cyprodinil-fludioxonil and as effective as cyprodinil. In four field experiments done in other states, chlorothalonil applied alone, cyprodinil-fludioxonil alternated with chlorothalonil, and cyprodinil alternated with chlorothalonil reduced severity of gummy stem blight on watermelon; however, these three treatments did not differ from each other in any experiment (Everts and Armentrout 2004; Everts and Zhou 2006; Seebold 2005; Thornton et al. 2005). In Georgia, efficacy of difenoconazole applied alone, difenoconazole rotated with chlorothalonil, and chlorothalonil applied alone did not differ (Langston and Sanders 2010). Fludioxonil alone has not been evaluated against gummy stem blight. It is not known why cyprodinil-fludioxonil and cyprodinil-difenoconazole alternated with chlorothalonil were more effective than chlorothalonil applied alone in two of the three field experiments in the current study but not in the previous studies. Severity of gummy stem blight was $\geq 76 \%$ on nontreated plants in four of the previous studies, which was very similar to severities observed in the current study (Everts and Armentrout 2004; Everts and Zhou 2006; Seebold 2005; Thornton et al. 2005).

Resistance to cyprodinil is common in certain populations of B. cinerea on fruit crops and in greenhouses, where the percentage of resistant isolates in the sampled population was close to or above 50\% (Amiri et al. 2013; Baroffio et al. 2003; Fernández-Ortuño et al. 2013; Leroch et al. 2013; Myresiotis et al. 2007). On crops of strawberry or blackberry in Europe or the southeastern United States and on greenhouse vegetables in Greece, cyprodinil was applied in a premixture with fludioxonil, yet resistance developed to cyprodinil. According to a recently published model that considers the population dynamics of fungicide-resistant isolates, resistance to cyprodinil developed in $B$. cinerea because there was no fitness cost associated with resistance (Mikaberidze et al. 2014). Cyprodinil-resistant isolates were as fit as cyprodinil-sensitive isolates when inoculated onto strawberry fruit treated or not treated with an anilinopyrimidine fungicide (Fernández-Ortuño et al. 2013). Isolates of D. bryoniae with single-gene mutations that confer resistance to thiophanate (FRAC group 1), QoI (FRAC group 11), or SDHI (FRAC group 7) fungicides are able to cause disease as readily as fungicide-sensitive isolates (Keinath 2009, 2012; Thomas et al. 2012a). These isolates have persisted in the southeastern United States (Thomas et al.

Table 4. Effective concentration (EC) that reduced relative colony diameter by $50 \%\left(\mathrm{EC}_{50}\right)$ values for 146 isolates of Didymella bryoniae grown on glucose minimal medium amended with fludioxonil and grouped by geographic, host, and environmental origins ${ }^{\mathrm{w}}$

\begin{tabular}{|c|c|c|c|c|c|c|c|c|c|}
\hline Group & $N$ & Mean & SD & Median & Min & Max & Range & $\mathbf{R F}^{\mathbf{x}}$ & Normality $(\operatorname{Pr}>W)^{y}$ \\
\hline \multicolumn{10}{|l|}{ State } \\
\hline South Carolina & 101 & 0.093 & 0.029 & 0.090 & 0.026 & 0.206 & 0.180 & 7.9 & 0.0005 \\
\hline Other states & 45 & 0.114 & 0.050 & 0.111 & 0.025 & 0.234 & 0.209 & 9.4 & 0.1672 \\
\hline$P$ value $\mathrm{z}^{\mathrm{z}}$ & & 0.033 & & & & & & & \\
\hline \multicolumn{10}{|l|}{ Host } \\
\hline Citrullus & 107 & 0.102 & 0.040 & 0.094 & 0.025 & 0.234 & 0.209 & 9.4 & $<0.0001$ \\
\hline Сиситis & 39 & 0.094 & 0.031 & 0.094 & 0.029 & 0.189 & 0.160 & 6.5 & 0.0435 \\
\hline$P$ value $\mathrm{z}$ & & 0.345 & & & & & & & \\
\hline \multicolumn{10}{|l|}{ Environment } \\
\hline Field & 105 & 0.098 & 0.032 & 0.094 & 0.026 & 0.234 & 0.208 & 9.0 & $<0.0001$ \\
\hline Greenhouse & 41 & 0.102 & 0.050 & 0.097 & 0.025 & 0.226 & 0.201 & 9.0 & 0.0101 \\
\hline$P$ value $\mathrm{z}$ & & 0.663 & & & & & & & \\
\hline
\end{tabular}

${ }^{\mathrm{w}} \mathrm{SD}=$ standard deviation, Min = minimum, and Max = maximum.

${ }^{\mathrm{x}}$ Resistance factor $(\mathrm{RF})=$ maximum $\mathrm{EC}_{50}$ divided by minimum $\mathrm{EC}_{50}$ (Gisi et al. 1997).

y Probability of a greater Shapiro-Wilk $W$ factor, a measure of normality.

${ }^{z}$ Probability that the means for the two groups immediately above do not differ, $F$ test from one-way analysis of variance.

Table 5. Efficacy of fungicides applied to control gummy stem blight on watermelon caused by pyraclostrobin- and boscalid-resistant isolates of $D$. bryoniae in autumn growing seasons in Charleston, $\mathrm{SC}^{\mathrm{w}}$

\begin{tabular}{|c|c|c|c|c|c|c|}
\hline \multirow[b]{2}{*}{ Treatment $^{\mathrm{z}}$} & \multicolumn{3}{|c|}{$\begin{array}{l}\text { Disease severity }(\%), 60 \text { to } 64 \\
\text { days after transplanting }\end{array}$} & \multicolumn{3}{|c|}{$\begin{array}{l}\text { Area under disease } \\
\text { progress curve }^{y}\end{array}$} \\
\hline & 2008 & 2009 & 2011 & 2008 & 2009 & 2011 \\
\hline Water & $77.2 \mathrm{a}$ & 78.9 a & $92.0 \mathrm{a}$ & $1,981 \mathrm{a}$ & $1,694 \mathrm{a}$ & $1,900 \mathrm{a}$ \\
\hline Boscalid-pyraclostrobin (Pristine 38WG) alternated with chlorothalonil & $62.7 \mathrm{ab}$ & $57.8 \mathrm{ab}$ & not done & $1,770 \mathrm{ab}$ & $1,263 \mathrm{ab}$ & not done \\
\hline Chlorothalonil (Bravo Weather Stik 6SC) & $42.4 \mathrm{bc}$ & $42.4 \mathrm{bc}$ & $21.0 \mathrm{~b}$ & $1,437 \mathrm{~b}$ & $1,095 \mathrm{~b}$ & $696 \mathrm{~b}$ \\
\hline Tebuconazole (Folicur 3.6F) alternated with chlorothalonil & $25.0 \mathrm{~cd}$ & $37.1 \mathrm{bc}$ & not done & $1,035 \mathrm{c}$ & $1,018 \mathrm{~b}$ & not done \\
\hline Cyprodinil-difenoconazole (Inspire Super 2.82SC) alternated with chlorothalonil & $15.1 \mathrm{~d}$ & $44.7 \mathrm{bc}$ & $8.3 \mathrm{c}$ & $762 \mathrm{~d}$ & $1,076 \mathrm{~b}$ & $442 \mathrm{bc}$ \\
\hline Cyprodinil-fludioxonil (Switch $62.5 \mathrm{WG}$ ) alternated with chlorothalonil & $16.9 \mathrm{~d}$ & $32.4 \mathrm{c}$ & $8.0 \mathrm{c}$ & $815 \mathrm{~d}$ & $933 \mathrm{~b}$ & $417 \mathrm{c}$ \\
\hline
\end{tabular}


2012a). Thus, it appears likely that cyprodinil-resistant isolates of D. bryoniae would be as fit as cyprodinil-sensitive isolates.

In the absence of multidrug resistant phenotypes, resistance to fludioxonil in populations of $B$. cinerea exposed to cyprodinilfludioxonil was low in Europe but higher in Florida (Amiri et al. 2013; Baroffio et al. 2003; Myresiotis et al. 2007). The multidrug resistant phenotype has been described only in $B$. cinerea from Europe (Leroch et al. 2013). The frequency of resistance to fludioxonil is expected to be less than for cyprodinil, because fludioxonil affects more than one gene involved in osmoregulation (Fungicide Resistance Action Committee 2015; Leroch et al. 2013). Because isolates of $B$. cinerea with reduced sensitivity to fludioxonil at $0.1 \mathrm{mg} / \mathrm{liter}$ appeared on strawberry treated with cyprodinil-fludioxonil, the same scenario is possible with D. bryoniae on cucurbits (Amiri et al. 2013). However, because $B$. cinerea produces substantially more conidia per lesion area $\left(10^{5}\right.$ to $10^{7}$ conidia $\left./ \mathrm{cm}^{2}\right)$ than $D$. bryoniae does (approximately 1.0 to $3.6 \times 10^{5} \mathrm{conidia} / \mathrm{cm}^{2}$ ), the chance of an isolate developing a mutation occurring in a gene targeted by a fungicide also is greater for B. cinerea (Keinath 2014; Sosa-Alvarez et al. 1995).

The risk of resistance to cyprodinil in $D$. bryoniae may be enhanced because of preexisting resistance to thiophanate-methyl, strobilurins, and boscalid. Recently, Li et al. (2014) demonstrated that $71 \%$ of the $B$. cinerea isolates from strawberry that were tripleresistant to thiophanate-methyl, pyraclostrobin, and boscalid became resistant to cyprodinil, whereas no isolates sensitive to these three fungicides were resistant to cyprodinil. If $D$. bryoniae follows a similar stepwise pattern of developing resistance to multiple fungicides, then isolates resistant to cyprodinil are likely to occur in Georgia or South Carolina. In Georgia, $82 \%$ of isolates of D. bryoniae were triple-resistant to thiophanate-methyl, azoxystrobin, and boscalid (Thomas et al. 2012a). Based on frequencies of isolates resistant to these three fungicides in South Carolina, $\geq 52 \%$ of isolates are predicted to be resistant to all three fungicides (Keinath 2008, 2009; Keinath and Zitter 1998).

Cyprodinil-fludioxonil currently is one of two fungicides registered for use on cucurbits in the United States that contains fludioxonil. Fludioxonil formulated alone is registered for use against Monosporascus root rot and vine decline on cucurbits, which is primarily a problem in the arid southwestern United States, where gummy stem blight does not occur (Martyn and Miller 1996). Cyprodinil and fludioxonil are the only anilinopyrimidine and phenylpyrrole fungicides, respectively, registered currently on cucurbits, so there is no risk of cross-resistance in $D$. bryoniae due to exposure to a related fungicide. Cyprodinil-fludioxonil (formulated as Switch) is a relatively expensive fungicide compared with other fungicides that also control gummy stem blight; currently, it costs more than twice as much as cyprodinil-difenoconazole (formulated as Inspire Super). Thus, it is unlikely that $D$. bryoniae will be exposed repeatedly to fludioxonil. In addition to cyprodinil-fludioxonil, cyprodinil is also the major component in cyprodinil-difenoconazole, in which it is mixed 3:1 with difenoconazole. The concentration of cyprodinil in both cyprodinil-containing fungicides is identical: 0.29 to $0.37 \mathrm{~kg} / \mathrm{ha}$ when the fungicides are applied at labeled rates. Both cyprodinil-fludioxonil and cyprodinil-difenoconazole are among the most effective fungicides currently registered to control gummy stem blight (Table 5) (Sanders and Langston 2013). Thus, populations of $D$. bryoniae, particularly those in the southeastern United States, where gummy stem blight is a common disease on watermelon and muskmelon, may be exposed two or more times per growing season or crop to cyprodinil. This would be less than the four to five applications of cyprodinil-containing fungicides currently allowed per crop. Although growing a subsequent cucurbit crop on polyethylene mulch used for a previous cucurbit crop is not recommended, because of the danger of carrying over inoculum of $D$. bryoniae, this practice has been observed (Keinath 2008). In addition to the increased risk of crop loss due to gummy stem blight, fungicide applications made to the second crop could increase the cumulative exposure of the pathogen to particular active ingredients.
Mixing fungicides with two different modes of action has been widely recommended as a strategy to delay development of resistance to fungicides with site-specific modes of action (Hobbelen et al. 2011; Staub 1991). Because D. bryoniae is sensitive to both cyprodinil and fludioxonil, using them as a mixture in cyprodinil-fludioxonil should delay resistance to each fungicide in this pathogen. In addition, because populations of D. bryoniae in South Carolina and Georgia are sensitive to difenoconazole, using cyprodinil-difenoconazole should reduce the selection pressure for resistance to cyprodinil and for reduced sensitivity to difenoconazole (Keinath and Hansen 2013; Thomas et al. 2012b).

Other ways to minimize the risk of fungicide resistance are to limit the total number of applications, the number of sequential applications, and the total amount of active ingredient applied per crop (Amiri et al. 2013; Myresiotis et al. 2007; Staub 1991). Because effective management of gummy stem blight requires regular, season-long fungicide applications, limiting the number of fungicide applications generally is accomplished by alternating fungicides with different modes of action to minimize applications of fungicides within the same FRAC group (Keinath 2000; Seebold 2005; Thomas et al. 2012a). The cyprodinil-difenoconazole and cyprodinil-fludioxonil labels specify a maximum of two sequential applications followed by one (cyprodinil-difenoconazole) or two (cyprodinil-fludioxonil) applications of fungicides with different active ingredients (i.e., fungicides not in FRAC groups 3 or 9 with cyprodinil-difenoconazole or FRAC groups 9 or 12 with cyprodinil-fludioxonil). Each cyprodinilcontaining fungicide, or a combination of the two, may be applied as many as five times per crop. Because of the potential for resistance development in $D$. bryoniae, it seems prudent to follow a strict alternation of active ingredients rather than the block alternation allowed for the two cyprodinil-containing fungicides.

Based on the efficacy of fungicides in the field portion of this study, tebuconazole (FRAC group 3) can be used in rotation with cyprodinil-fludioxonil, and chlorothalonil (FRAC group M5) or mancozeb (FRAC group M3) can be used in rotation with cyprodinil-fludioxonil, cyprodinil-difenoconazole, or tebuconazole. This rotation sequence will limit the number of applications of the cyprodinil-containing fungicide to three per season (Table 1). If both tebuconazole and chlorothalonil are used in rotation with cyprodinilfludioxonil, then the number of applications of cyprodinil can be reduced further. Isolates of $B$. cinere $a$ with resistance to multiple fungicides were more likely to be found in fields treated more than 12 times per season with site-specific fungicides whereas, in fields treated less than five times per season, isolates that were sensitive to all or all but one fungicide were found ( $\mathrm{Li}$ et al. 2014). Currently, chlorothalonil, tebuconazole, and mancozeb cost less than one-third as much as the cyprodinil-containing fungicides. However, use of these three fungicides is difficult during the harvest period. Tebuconazole, like most FRAC group 3 fungicides, has a 7-day preharvest interval on cucurbits, which precludes its use on muskmelon, cucumber, and watermelon after harvesting begins. The chlorothalonil label cautions against using this fungicide on watermelon within 21 days of harvest when the weather is sunny and the temperature is $>32^{\circ} \mathrm{C}$. The preharvest interval of 5 days for mancozeb fits the typical harvest schedule for watermelon but not muskmelon or cucumber. Thus, cyprodinilfludioxonil is uniquely suited for application on cucurbits during the harvest period to suppress gummy stem blight.

In conclusion, $D$. bryoniae was less sensitive to cyprodinil and fludioxonil than $B$. cinerea, the ascomycete pathogen most frequently characterized for sensitivities to these two fungicides. The greatest risk for resistance in D. bryoniae appears to be to cyprodinil, because (i) it is a component of two fungicides currently used to manage gummy stem blight on cucurbits, (ii) resistance involves a singlegene mutation, (iii) it is systemic in plants, and (iv) resistance to cyprodinil in $B$. cinerea was more likely to occur in isolates already resistant to thiophanate-methyl, strobilurin fungicides, and boscalid (Hilber and Hilber-Bodmer 1998; Li et al. 2014). Thus, prudent fungicide rotations on cucurbits that include two or more active ingredients should be followed to reduce the risk of fungicide resistance in D. bryoniae. 


\section{Acknowledgments}

I thank C. D. Conrad, C. M. Keinath, V. B. DuBose, A. W. Lassiter, J. A. Dufault, and G. V. Baccari for technical assistance; K. Berry, K. Everts, T. Isakeit, G. Hoyos, S. Koike, T. Kucharek, and D. Sumner for providing isolates of D. bryoniae from states other than South Carolina; and A. Tally, Syngenta Crop Protection, for providing technical-grade fungicide active ingredients.

\section{Literature Cited}

Amiri, A., Heath, S. M., and Peres, N. A. 2013. Phenotypic characterization of multifungicide resistance in Botrytis cinerea isolates from strawberry fields in Florida. Plant Dis. 97:393-401

Anonymous. 2007. Crop Profile for Cucumbers in New Jersey. National Information System of the Regional Integrated Pest Management Centers. Online publication: http://www.ipmcenters.org/CropProfiles/index.cfm

Baroffio, C. A., Siegfried, W., and Hilber, U. W. 2003. Long-term monitoring for resistance of Botryotinia fuckeliana to anilinopyrimidine, phenylpyrrole, and hydroxyanilide fungicides in Switzerland. Plant Dis. 87:662-666.

Everts, K. L., and Armentrout, D. K. 2004. Evaluation of fungicides for managing gummy stem blight on watermelon, 2003. Fungic. Nematic. Tests 59:V047. Online publication.

Everts, K. L., and Zhou, X. G. 2006. Evaluation of fungicides for management of gummy stem blight and Cercospora leaf spot on watermelon, 2005. Fungic. Nematic. Tests 61:V008. Online publication.

Fernández-Ortuño, D., Chen, F., and Schnabel, G. 2013. Resistance to cyprodinil and lack of fludioxonil resistance in Botrytis cinerea isolates from strawberry in North and South Carolina. Plant Dis. 97:81-85.

Fungicide Resistance Action Committee. 2015. FRAC Code List. Fungicides sorted by mode of action (including FRAC Code numbering). Online publication: http://www.frac.info/docs/default-source/publications/frac-code-list/ frac-code-list-2015-final

Gachango, E., Hanson, L. E., Rojas, A., Hao, J. J., and Kirk, W. W. 2012. Fusarium spp. causing dry rot of seed potato tubers in Michigan and their sensitivity to fungicides. Plant Dis. 96:1767-1774.

Gisi, U., Herman, D., Ohl, L., and Steden, C. 1997. Sensitivity profiles of Mycosphaerella graminicola and Phytophthora infestans populations to different classes of fungicides. Pestic. Sci. 51:290-298.

Hilber, U. W., and Hilber-Bodmer, M. 1998. Genetic basis and monitoring of resistance of Botryotinia fuckeliana to anilinopyrimidines. Plant Dis. 82:496-500.

Hilber, U. W., and Schüepp, H. 1996. A reliable method for testing the sensitivity of Botryotinia fuckeliana to anilinopyrimidines in vitro. Pestic. Sci. 47:241-247.

Hobbelen, P. H. F., Paveley, N. D., and van den Bosch, F. 2011. Delaying selection for fungicide insensitivity by mixing fungicides at a low and high risk of resistance development: A modeling analysis. Phytopathology 101:1224-1233.

Iacomi-Vasilescu, B., Avenot, H., Bataillé-Simoneau, N., Laurent, E., Guénard, M., and Simoneau, P. 2004. In vitro fungicide sensitivity of Alternaria species pathogenic to crucifers and identification of Alternaria brassicicola field isolates highly resistant to both dicarboximides and phenylpyrroles. Crop Prot. 23:481-488.

Kanetis, L., Förster, H., and Adaskaveg, J. E. 2008. Baseline sensitivities for new postharvest fungicides against Penicillium spp. on citrus and multiple resistance evaluations in P. digitatum. Plant Dis. 92:301-310.

Kanetis, L., Förster, H., and Adaskaveg, J. E. 2010. Determination of natural resistance frequencies in Penicillium digitatum using a new air sampling method and characterization of fludioxonil- and pyrimethanil resistant isolates. Phytopathology 100:738-746.

Keinath, A. P. 2000. Effect of protectant fungicide application schedules on gummy stem blight epidemics and marketable yield of watermelon. Plant Dis. $84: 254-260$

Keinath, A. P. 2008. Survival of Didymella bryoniae in infested muskmelon crowns in South Carolina. Plant Dis. 92:1223-1228.

Keinath, A. P. 2009. Sensitivity to azoxystrobin in Didymella bryoniae isolates collected before and after field use of strobilurin fungicides. Pest Manage. Sci. 65:1090-1096.

Keinath, A. P. 2012. Differential sensitivity to boscalid in conidia and ascospores of Didymella bryoniae and frequency of boscalid-insensitive isolates in South Carolina. Plant Dis. 96:228-234.

Keinath, A. P. 2013. Susceptibility of cucurbit rootstocks to Didymella bryoniae and control of gummy stem blight on grafted watermelon seedlings with fungicides. Plant Dis. 97:1018-1024.

Keinath, A. P. 2014. Reproduction of Didymella bryoniae on nine species of cucurbits under field conditions. Plant Dis. 98:1379-1386.

Keinath, A. P., and DuBose, V. B. 2009. Evaluation of triazoles and other fungicides for control of gummy stem blight on watermelon, 2008. Plant Dis. Manage. Rep. 3:V034. Online publication.
Keinath, A. P., DuBose, V. B., and Baccari, G. V. 2010. Evaluation of fungicide programs with chlorothalonil for control of gummy stem blight on watermelon, 2009. Plant Dis. Manage. Rep. 4:V012. Online publication.

Keinath, A. P., DuBose, V. B., and Dufault, J. A. 2012. Evaluation of fungicide programs that included chlorothalonil against gummy stem blight on watermelon, 2011. Plant Dis. Manage. Rep. 6:V023. Online publication.

Keinath, A. P., DuBose, V. B., May, W. H., III, and Cantrell, J. P. 2001. Evaluation of strobilurins and tebuconazole for control of gummy stem blight on watermelon. Fungic. Nematic. Tests 56:V119.

Keinath, A. P., Everts, K. L., Langston, D. B., Jr., Egel, D. S., and Holmes, G. J. 2007 Multi-state evaluation of reduced-risk fungicides and Melcast against Alternaria leaf blight and gummy stem blight on muskmelon. Crop Prot. 26: 1251-1258.

Keinath, A. P., and Hansen, Z. R. 2013. Isolates of Didymella bryoniae from South Carolina remain sensitive to DMI fungicides despite multi-year exposure. J. Phytopathol. 161:315-323.

Keinath, A. P., and Zitter, T. A. 1998. Resistance to benomyl and thiophanatemethyl in Didymella bryoniae from South Carolina and New York. Plant Dis. 82:479-484.

Kothera, R. T., Keinath, A. P., Dean, R. A., and Farnham, M. W. 2003. AFLP analysis of a worldwide collection of Didymella bryoniae. Mycol. Res. 107:297-304.

Langston, D. B., Jr., and Sanders, F. H., Jr. 2010. Evaluation of fungicide sprays on gummy stem blight of watermelon in Georgia IV, 2009. Plant Dis. Manage. Rep. 4:V139. Online publication.

Leroch, M., Plesken, C., Weber, R. W. S., Kauff, F., Scalliet, G., and Hahn, M. 2013. Gray mold populations in German strawberry fields are resistant to multiple fungicides and dominated by a novel clade closely related to Botrytis cinerea. Appl. Environ. Microbiol. 79:159-167.

Li, H. X., and Xiao, C. L. 2008. Baseline sensitivities to fludioxonil and pyrimethanil in Penicillium expansum populations from apple in Washington State. Postharvest Biol. Technol. 47:239-245.

Li, X., Fernández-Ortuño, D., Chen, S., Grabke, A., Luo, C.-X., Bridges, W. C., and Schnabel, G. 2014. Location-specific fungicide resistance profiles and evidence for stepwise accumulation of resistance in Botrytis cinerea. Plant Dis. 98:1066-1074.

Martyn, R. D., and Miller, M. E. 1996. Monosporascus Root Rot and Vine Decline. Pages 18-19 in: Compendium of Cucurbit Diseases. T. A. Zitter, C. E. Thomas, and D. L. Hopkins, eds. American Phytopathological Society, St. Paul, MN.

Mikaberidze, A., McDonald, B. A., and Bonhoeffer, S. 2014. Can high-risk fungicides be used in mixtures without selecting for fungicide resistance? Phytopathology 104:324-331.

Myresiotis, C. K., Karaoglanidis, G. S., and Tzavella-Klonari, K. 2007. Resistance of Botrytis cinerea isolates from vegetable crops to anilinopyrimidine, phenylpyrrole, hydroxyanilide, benzimidazole, and dicarboximide fungicides. Plant Dis. 91:407-413.

Sanders, F. H., Jr., and Langston, D. B., Jr. 2013. Evaluation of fungicide sprays on gummy stem blight of watermelon in Georgia I, 2012. Plant Dis. Manage. Rep. 7:V132. Online publication.

Seebold, K. W., Jr. 2005. Evaluation of Pristine, Switch, and Vanguard for control of gummy stem blight in watermelon, 2004. Fungic. Nematic. Tests 60:V127. Online publication.

Shaner, G., and Finney, R. E. 1977. The effect of nitrogen fertilization on the expression of slow-mildewing resistance in Knox wheat. Phytopathology 67:1051-1056.

Sosa-Alvarez, M., Madden, L. V., and Ellis, M. A. 1995. Effects of temperature and wetness duration on sporulation of Botrytis cinerea on strawberry leaf lesions. Plant Dis. 79:609-615.

Staub, T. 1991. Fungicide resistance: Practical experience with antiresistance strategies and the role of integrated use. Annu. Rev. Phytopathol. 29:421-442.

Stevenson, K. L., Langston, D. B., Jr., and Seebold, K. W. 2004. Resistance to azoxystrobin in the gummy stem blight pathogen documented in Georgia Online publication. Plant Health Prog. 10.1094/PHP-2004-1207-01-RS.

Thomas, A., Langston, D. B., Jr., Sanders, H. F., and Stevenson, K. L. 2012a. Relationship between fungicide sensitivity and control of gummy stem blight of watermelon under field conditions. Plant Dis. 96:1780-1784.

Thomas, A., Langston, D. B., Jr., and Stevenson, K. L. 2012b. Baseline sensitivity and cross-resistance to succinate-dehydrogenase-inhibiting and demethylationinhibiting fungicides in Didymella bryoniae. Plant Dis. 96:979-984.

Thornton, A. C., Adams, M. L., and Holmes, G. J. 2005. Evaluation of fungicides for control of gummy stem blight of watermelon, 2004. Fungic. Nematic. Tests 60:V05. Online publication.

Zhao, H., Kim, Y. K., Huang, L., and Xiao, C. L. 2010. Resistance to thiabendazole and baseline sensitivity to fludioxonil and pyrimethanil in Botrytis cinerea populations from apple and pear in Washington State. Postharvest Biol. Technol. 56:12-18. 